Comparative Philosophy Volume 8, No. 2 (2017): 106-110

Open Access / ISSN 2151-6014

www.comparativephilosophy.org

\title{
IN MEMORIAM: RICHARD LANE TIESZEN 1951-2017
}

Richard (Rick) Lane Tieszen, Professor of Philosophy at San José State University and a member of our Advisory Board, passed away on $28^{\text {th }}$ March 2017 due to multiple myeloma. Rick has made his valuable contribution to the development of this peer-reviewed open-access international journal in philosophy both as a member of its international Advisory Board and as its article contributor and peer reviewer. Rick is survived by his wife Nancy, his parents James and Beverly Tieszen, and his sisters Sandra Tait, Patricia Anderson, and Pamela Hobbs.

1.

Rick was born in Mitchell, South Dakota, in 1951. He graduated from Colorado State University in Fort Collins in 1974, received an M.A. from the Graduate Faculty of the New School for Social Research in 1978 and a Ph.D. in Philosophy from Columbia University in 1987 (with Charles Parsons as principal advisor of his dissertation). After briefly teaching at New York University, Lake Forest College and Miami University, Rick joined San José State University in 1989.

Rick is an internationally renowned scholar in phenomenology, logic and philosophy of mathematics. He was the author of three influential books: After Gödel: Platonism and Rationalism in Mathematics and Logic (Oxford University Press, 2011), Phenomenology, Logic, and the Philosophy of Mathematics (Cambridge University Press, 2005), and Mathematical Intuition: Phenomenology and Mathematical Knowledge ("Synthese Library" series Volume 203) (Kluwer [now Springer], 1989). He is the author of over fifty articles in well regarded journals including Philosophia Mathematica, Continental Philosophy of Science, Philosophy and Phenomenological Research, Synthese, and History and Philosophy of Logic. Rick co-edited the anthology Between Logic and Intuition: Essays in Honor of Charles Parsons (with Gila Sher, Cambridge University Press, 2000) and the anthology Constructive Engagement of Analytic and Continental Approaches in Philosophy: From the Vantage Point of Comparative Philosophy (with Bo Mou, Brill, 2013). His important work in logic and the foundation of mathematics was recognized by a prestigious National Endowment for the Humanities award for 20062007. Rick's last publication, Simply Gödel (Simply Charly, 2017), an exposition of Gödel's work for a general audience, was in press at the time of his death. ${ }^{1}$

\footnotetext{
${ }^{1}$ Several weeks before Rick passed away when the doctors gave up the hope of further treatment and he had to enter the hospice in San Francisco, Dagfinn Føllesdal visited him and spent a week, planning a joint publication, of Gödel's notes on Husserl's writings, with commentary. This might appear soon.
} 
2.

As suggested by the title of his aforementioned book Phenomenology, Logic, and the Philosophy of Mathematics, one distinguishing characteristic feature of Rick's scholarly work lies in its breadth and depth crossing the divide between analytic and "Continental" approaches in philosophy, given that "phenomenology" is one of the central coverages of the European "Continental" philosophy while logic and philosophy of mathematics is among the base concerns of the analytic tradition in philosophy that are closely related to science and human mental power. In the "preface" for his book After Gödel, Rick wrote that "[a] final general point that I would like to make [is this]...That Gödel, who is one of the greatest logicians of all time, should have found Husserl to be the most interesting philosopher since Leibniz, and not thinkers such as Carnap, Wittgensteain, Schlick, and others, speak volumes about the division that occurred between so-called analytic and Continental philosophy. In spite of the fact that this division has been institutionalized in various professional organizations, university curricula, university hiring practices, and myriad other ways, there are many respects in which it is artificial and should be resisted. I hope that upcoming generations of thinkers will look back with puzzlement on its episodes of rancor, exclusion, and small-mindedness." (viii). As highlighted by Dagfinn Føllesdal, "Tieszen has long been one of the bridge builders in contemporary philosophy, who is engaged by the philosophical issues and studies them with a broad background and an open mind.",

With such a vision and his in-depth understanding of the philosophical nature and methodological structure of the analytic and "Continental" approaches within the Western philosophical tradition, it was quite natural for Rick to give his enthusiastic and substantial endorsement when I suggested an expanded conception of the identities of analytic and "Continental" approaches in philosophy in view of their distinct and representative methodological features, which are not restricted to the Western tradition but in essence represent two distinct methodological orientations that manifest themselves in different culture-associated philosophical traditions in distinct philosophically-interesting ways, instead of the Western tradition only. ${ }^{3}$ This has led to our substantial and enjoyable academic cooperation to work on a collective research project Constructive Engagement of Analytic and Continental Approaches in Philosophy: From the Vantage Point of Comparative Philosophy, which was carried out through a range of distinct workshops on the same theme ${ }^{4}$ and whose result is the

\footnotetext{
${ }^{2}$ Cited from Dagfinn Føllesdal's review on Rick's book After Gödel (Oxford, 2011), in Philosophia Mathematica (2016) 24.3: 405-217.

${ }^{3}$ For example, in classical Chinese philosophy, one can identify the "analytic"-oriented resources in, say, Gongsun Long's and the Later Mohist literature as well as the "Continental"-oriented resources in, say, philosophical Daoism (for instance, the well-known classical Daoist text, the Dao-De-Jing, is literally a philosophical poem). To this extent, the "analytic" and "Continental" methodological strands and elements have been intrinsic parts of classical Chinese philosophy, rather than "borrowed" or "imposed" from "Western" philosophies later on in contemporary studies of Chinese philosophy.

${ }^{4}$ They were respectively held at SJSU $\left(10^{\text {th }}\right.$ April 2010, as the 2010 term of the SJSU Center for Comparative Philosophy Workshop Series), Peking University ( $6^{\text {th }}$ August 2010, as the 2010 term of the "Beijing Roundtable on Contemporary Philosophy" Workshop Series), and the APA Pacific
} 
anthology volume bearing the same title (Brill, 2013). Indeed, exploration of the relation between analytic and "Continental" approaches in philosophy is not new; what distinguishes this book project is its vantage point of comparative philosophy and its goal of cross-tradition constructive engagement, as highlighted in its title.

This has happened also in the background in which comparative philosophy has undergone a significant development in its identity, coverage and mission, especially since the beginning of this century. It is no longer limited exclusively to East-West dialogue nor is it restricted to examining regional and cultural traditions. It does not stop at a mere historical description of apparent similarities and differences of views under examination, but it penetrates deeper and wider philosophically. Instead of being a local subfield of philosophy, it has become an exciting general front of philosophical exploration that has been labeled the 'constructive engagement' goal and methodology. Constructive engagement, as we understand it, involves the exploration of how, by way of reflective criticism (including self-criticism) and argumentation and with the guidance of adequate methodological guiding principles, distinct approaches from different philosophical traditions (understood broadly, whether distinguished culturally or by styles and orientations) can learn from each other and jointly contribute to the contemporary development of philosophy on a range of philosophical issues or topics, which can be jointly concerned and approached through appropriate philosophical interpretation and from a broader philosophical vantage point. This is one central concern and goal of comparative philosophy when it is understood as a way of doing philosophy comparatively.

In this way, we agree that there are two significant, distinct but complementary, "cross-tradition" fronts, with their distinct emphases and focuses, on which to effectively carry out and implement the project of constructive engagement of analytic and "Continental" philosophy. One front is to explore the issue with the focus on relevant resources within the Western philosophical tradition but treat them from the vantage point of comparative philosophy: they are essentially treated as two distinct but complementary methodological orientations of doing philosophy and are examined in the foregoing constructive-engagement way. Another front consists of referring to the resources of the two approaches also beyond the Western tradition. It is known that, historically speaking, the two labels 'analytic' and 'Continental' have been used by many to refer to the two styles and orientations of doing philosophy within the Western philosophical tradition, as literally suggested by the label 'European Continent(al)'; however, since the primary interest and purpose of this anthology book on the topic does not consist in doing history but in philosophical inquiry, and since some characteristic features of the two distinct types of methodological styles and orientations of doing philosophy can be traced back to ancient sources in the Western and other philosophical traditions and have also manifested themselves in other philosophical traditions in distinct philosophicallyinteresting ways, we thus agreed that the contributions to the volume were organized

Division 2011 meeting in San Diego (21 ${ }^{\text {st }}$ April 2011, as a special panel session arranged by the APA Committee on the Status of Asian and Asian-American Philosophers and Philosophies). 
in a way that reflects the two fronts and that can serve the distinct needs of various readers while capturing the same central point of doing philosophy comparatively: showing how distinct approaches and resources from different philosophical traditions that well manifest the two methodological orientations can provide broad visions, complementary perspectives, and other valuable or even indispensable resources in order to enhance our understanding and treatment of a range of jointlyconcerned philosophical topics. In this way, the aforementioned anthology book consists of two parts with their distinct focuses while being complementary as a whole. Part I of the volume consists of essays that focus on relevant resources in the Western tradition, while Part II consists of essays that include resources from other traditions. In addition to our co-authored "General Introduction" to the whole volume, with our distinct but complementary expertise backgrounds and emphases, Rick provided his introduction to Part I, while I provided mine to Part II, both of which, together with our own respective contributing essays, are given from the "constructive-engagement" vantage point of comparative philosophy. ${ }^{5}$ I have learnt a lot from Rick in this unique, effective and enjoyable scholarly co-operation project.

With much said on Rick's academic co-operation work directly relevant to the central concern of this journal, I would like to indicate one more relevant dimension of Rick's work: with his "comparative philosophy" vision and international foresight, Rick has paid much attention to international cooperation and academic exchange in both research and education. He held visiting appointments at several institutions in Europe: Ecole des hautes études en sciences sociales (EHESS, Paris), Archives Henri Poincaré/CNRS/ Université, Institut d'histoire et de philosophie des sciences et des techniques (IHPST/CNRS), and Universiteit Utrecht. Rick co-supervised HE Haoping (then a Ph.D. Candidates in philosophy from Peking University, China) in his dissertation writing concerning philosophy of math and phenomenology when HE as a Visiting Scholar did research at SJSU during the 2012-13.

3.

On a more personal level, I have also learnt a lot from Rick. In the past sixteen years since I joined SJSU in 2000, either at the faculty meetings or at other academic occasions or at the casual get-togethers, no matter on whatever things (either some big issues, controversial topics, course assignments, etc.), I have first-hand experienced, and have been deeply impressed by, Rick's highly rational attitude, considerate and fair treatment, modest and gentle manner, and sincere mutual-respect without pretentious arrogance. I strive to learn from him in these connections.

The last email communication I received from Rick was around late-January before the Chinese New Year this year. I cite a relative long part of it below as that part can give a look at how Rick was then leading the meaningful life with his

\footnotetext{
${ }^{5}$ The titles of Rick's and my own contributing essays to the volume more or less reflect how the content of this book distinguishes itself from the traditional discussion on the issue from the vantage point of comparative philosophy in the global context: Rick's article is entitled "Analytic and Continental Philosophy, Science, and Global Philosophy" (103-124), while mine "On Daoist Approach to the Issue of Being in Engaging Quinean and Heideggerian Approaches" (289-319).
} 
optimistic life attitude and in an enjoyment mood of doing his last scholarly work while his health was in decline during his last months. Rick wrote:

Soon it will be time for what people here call "Chinese New Year" (or "Spring Festival")....I am now reading an editor's mark-up of my new book, Simply Gödel. This is an ebook I was invited to write for a general audience. It was fun to write. Since I have been teaching much of Gödel's work for twenty-five years or so, the only part I had to research was the biographical material about his life. Also, several papers have recently been published, one in Inquiry, another in Phenomenology and the Cognitive Sciences and some others. As for my health, I am not doing well. I am in decline now but I have just started some new medicine that will hopefully be effective....

Although I was sensing that this time Rick was in a more adverse situation, his optimistic attitude, the possible effectiveness of the mentioned new medicine, and the past history of his several partial recoveries since the attack of his illness in 2012 did also bear on my mixed sentiment: though being sensitive to not interrupting his private life during the treatment, I did felt the need to pay my visit to Rick, while I believe I could still make it during the coming spring break around the end of March. But it was too late: Rick already passed away on $28^{\text {th }}$ March, right at the beginning of the spring break. When hearing the bad news, I was shocked; with tears in my eyes, I so regretted losing the last chance to say the final goodbye to Rick.

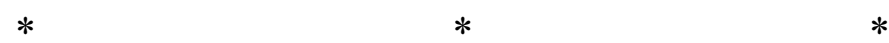

Rick has been still alive deep in my heart: his vision of cross-tradition engagement, his distinguished scholarship, and his rational, modest and kind way of handling things continue to inspire me in my journey. He spent his final days, and passed away peacefully, in Zen Hospice in San Francisco, where Daoist and Buddhist insights on life and death would be subtly immersed in the setting. ${ }^{6}$ Perhaps a Daoist insight on life and death as given by Lao Zi (an ancient Daoist philosopher) in the Dao-De-Jing (Ch. 33) would well fit in: “不失其所者久, 死而不亡者壽” (my translation: “One who does not fail in holding one's due ground will endure; One who dies and yet does not perish enjoys longevity."). Rick is such a person in my heart. ${ }^{7}$

Bo Mou

$26^{\text {th }}$ July 2017

\footnotetext{
${ }^{6}$ Zen (Buddhism) is another name for Chan (禪) Buddhism that resulted from the combination of Mahayana Buddhism and philosophical Daoism after Buddhism was spread to China as early as $1^{\text {st }}$ century CE ('Zen' is the transliteration of the pronouncement in Japanese of the Chinese character '禪' whose English transliteration is 'Chan').

${ }^{7}$ Though with my own emphasis in this memorial writing, for some of the historical facts mentioned here, I have referred to the two other memorial articles, written respectively by Charles Parsons (whose version of $20^{\text {th }}$ June 2017 was provided by Dagfinn Føllesdal, forthcoming in Philosophphia Mathematica) and by Rita Manning (posted at SJSU Philosophy Department's website, http://www. sjsu.edu/philosophy/ RickTieszen Memorian/), and the relevant information in Dagfinn Føllesdal's email of $3^{\text {rd }}$ July 2017.
} 